\title{
6331 Sayılı İ̧̧ Sağlığı ve Güvenliği Kanunu’nda Çalışanın Çalışmaktan Kaçınma Hakkı ve Koronavirüs Salgını
}

\author{
6331 Occupational Health and Safety Law: \\ Employee's Right to Avoid Working and Covid-19 Outbreak
}

Metin PEHLiVAN

\begin{abstract}
ÖZET
6331 sayılı İş Sağlığı ve Güvenliği Kanunu, istisnalar dışında hem kamu hem de özel sektördeki çalışanların tümünü kapsama dahil etmiştir. Buna bağlı olarak da işverenler ve çalışanlar birçok yükümlülük altına girmiştir. İşverenlere de işyerinde yükümlülüklere uygun hareket görevi yüklenmiştir. Kanun, çalışanlara da işverenlerin bu yükümlülüğü uygun hal ve davranışta bulunmaması halinde diğer şartlarında gerçekleşmesiyle çalışmaktan kaçınma hakkı tanımıştır. Eğer işveren iş sağlığı ve güvenliği tedbirlerini almaz, birçok riskin ortaya çımasına neden olursa, çalışanın riskli bir ortamda çalışma hususunda zorlayamaz. Bir işyerinde iş sağlığı ve güvenliği yükümlülükleri yerine getirilmemesinden kaynaklı riskler ortaya çıkmışsa işçiler iş sözleşmesini feshedebileceği gibi şartların gerçekleşmesi halinde geçici süreli de olsa çalışmaktan kaçınabilecektir. Koronavirüs salgının çalışma hayatını etkilediği bu dönemde çalışanın çalışmaktan kaçınma hakkının çerçevesi hakkında bilgi sahibi olunması da büyük önem arz etmektedir.
\end{abstract}

Anahtar Kelimeler: Tehlikeler, Çalışmaktan Kaçınma, İş Sağlığı ve Güvenliği, Koronavirüs

\section{ABSTRACT}

The Occupational Health and Safety Law No. 6331 includes all public and private sector employees with the exceptions. Accordingly, both employers and employees have many obligations. Employers are also obliged to provide occupational health and safety in the workplace. In case the employers do not fulfill this obligation, the right to refrain from working when the conditions are fulfilled is enforced. If the employer does not take occupational health and safety measures and causes many risks, it cannot make it compulsory for the employee to work in a risky environment. If risks arise from the failure to meet occupational health and safety obligations in a workplace, workers may terminate the employment contract and, if conditions are met, may temporarily refrain from working. It is also of great importance for the employee to know about the framework of the right to refrain from working in this period when the corona virus epidemic affects the working life.

Keywords: Occupational Health and Safety, Avoid Working, Danger, Covid-19

Metin PEHLivAN | metinpehlivan@klu.edu.tr.com

Kırklareli Üniversitesi, İş ve Sosyal Güvenlik Hukuku Anabilim Dalı, Kırklareli, Türkiye

Kırklareli University, Department of Labour and Social Security Law, Kırklareli, Turkey 


\section{GIIRIŞ}

İnsan sağlığını korumak ve geliştirmek, içinde yaşanılan dönemde gelişmiş ve gelişmekte olan ülkeler tarafından önemsenmektedir. Çalışanların görevlerini yerine getirirken, edimlerini ifa ederken gerek ruhen gerekse bedenen sağlıklı ve güvenli bir ortamda çalışmaları önem arz etmektedir. $\mathrm{Bu}$ durum hem kendileri hem işverenleri hem ailesi hem de içinde yaşadıkları toplum yönünden de aynı şekilde önem arz etmektedir.

Gerek ulusal gerekse uluslararası hukuk normları bakımından çalışanın yaşam hakkının önemsenmesi, korunması birçok düzenlemeyi içermektedir. Bireylerin yaşam haklarının varllğı ve korunması hakkı, çalışanların ruhi ve bedeni varlıklarının korunmasına yönelik birçok düzenleme ulusal ve uluslararası hukuktaki düzenlemelerde mevcuttur. Uluslararası Hukukta Türkiye’nin de imzaladığı 155 sayılı Uluslararası Çalışma Sözleşmesinin 13.maddesinde de çalışmaktan kaçınma hakkı düzenlenmiştir. İlgili hükme göre çalışanlar işyerinde sağlıkları ve yaşamları için ciddi ve yakın tehlike gördüklerinde çalışmaktan kaçınabilecekler.

6331 sayılı İş Sağlığı ve Güvenliği Kanunu yürürlüğe girmesinden sonra çalışanın işyerinde sağlıklı ve güvenli bir şekilde çalışmasını güvence altına hükümlere yer verilmiş, kanunun uygulanmasına yardımcı olacak olan yönetmelikler de düzenlenmiştir. 6331 sayılı İş Sağlı̆̆ı ve Güvenliği Kanunu yürürlüğe girmeden önce 4857 sayılı İş Kanunu madde 83'te işçinin çalışmaktan kaçınma hakkı düzenlenmişti. Çalışanın çalışmaktan kaçınma hakkı İş Sağlığı ve Güvenliği Kanunu’nda da 13.maddede hüküm altına alınmıştır. İlgili kanun hükmünde çalışanlar kanunda belirtilen şartların gerçekleşmesi durumunda işyerinde ciddi ve yakın tehlikenin varlığında çalışmaktan kaçınabilecektir. İş Sağl1ğ1 ve Güvenliği Hizmetleri Yönetmeliği madde 8'de de çalışanların sağlık ve güvenliklerini etkileyebilecek tehlike- lerin ortaya çıkmasıyla birlikte iş sağlığı ve güvenliği kuruluna söz konusu tehlikeleri bildireceği, kurulun oluşturulmadığı işyerlerinde ise işverene bildirilerek durumun tespit edilmesi ve gerekli önlemlerin alınması sağlanabilecektir.

Koronavirüs salgın hastalığının çalışma hayatını etkilediği bu dönem çalışanın çalışmaktan kaçınma hakkı büyük önem arz etmektedir. Bu bakımından bu makalede çalışanın çalışmaktan kaçınma hakkının unsurları ve sonuçlarını irdelenecektir. Koronavirüs salgın hastalığının işyerlerinde çalışanlar arasında tespit edilmesi halinde işverenin gerekli tedbirleri almakla yükümlülüğü vurgulanacak, aksi takdirde çalışanların çalışmaktan kaçınma hakkını kullanabileceğine yer verilecektir.

\section{A. Genel Olarak}

İş sağlığı ve güvenliği sistem olarak çalışanın hem ruhen hem de bedenen korunmasını amaçlamaktadır. Bundan dolayı da işs sağlığı ve güvenliğine yönelik düzenlenen kanun ve yönetmelikler, çalşan sağlığı ve güvenliğine yönelik tehditleri önleyici düzenlemelerdir. İşverenler işyerindeki tüm çalışanları hem bedenen hem de ruhen korumak, bunun için gerekli olan bütün tedbirleri almakla yükümlüdür. Çünkü işyerinde ortaya çıkabilecek riskleri belirlemek ve bu riskleri en alt seviye indirmek iş sağlığı ve güvenliği müessesesinin öncelikli amaçlarındandır. Bu amacın gerçekleşmesinde üç saç ayağı olan devlet, işveren ve çalışana da bazı sorumluluklar yüklenmektedir. İş sağlığı ve güvenliği kültürünün oluşmasında devlet işs sağlığı ve güvenliği kanuni düzenlemelere giderek, gerekli denetimlerde bulunarak sorumluluğunu yerine getirdiği gibi işverenler de bu düzenlemelerin uygulanmasını, gerekli tedbirlerin alınmasını sağlayarak katkı sağlamaktadırlar. Çalışanlar da işyerinde meydana gelecek tehlikelerin önlenmesine yönelik işyeri uygulamalarının belirlenmesine, risk değerlendirme aşamalarına bilgi ve tecrübe desteği vererek, katkı sağlanmakta- 
dır. Sonuç olarak iş sağlığı ve güvenliğinin ana çekirdeğini insan yani çalışan oluşturmaktadır. Çalışanın da Anayasal bir hak olan yaşama hakkının hem devlet hem işveren hem de bizzat çalışan tarafından korunması iş sağlığı ve güvenliğinin temel amacıdır.

Çalışan, çalışma hayatına adımını attığı ilk andan itibaren çalışıı̆̆ ortama bağlı olarak birçok mesleki riskle karşılaşmakta, iş kazasına veya meslek hastalığına yakalanmakta, ruhen veya bedenen tehlikelerle karşı karşıya gelmektedir. Bundan dolayı çalışanların işyerinde çalışma ortamından kaynaklı tehlikelerle mücadele etmeleri zorunluluk arz etmektedir. Bu hususun iş hukukundaki görünümü ise işverenin borçlarından biri olan işçiyi koruma borcunda kendini göstermektedir. Türk Borçlar Kanunu 417. Maddesinde işçinin korunmasına yönelik hüküm yer almaktadır. İlgili hükme göre "İ̧vveren, hizmet ilişkisinde işşinin kişiliğini korumak ve sayg göstermek ve işyerinde dürüstlük ilkelerine uygun bir düzeni sağlamakla, özellikle işcilerin psikolojik ve cinsel tacize uğramamalar ve bu tür tacizlere uğramıs olanların daha fazla zarar görmemeleri için gerekli önlemleri almakla yükümlüdür". İşverenin işçisini işyerinde meydana gelebilecek tehlikelere karşı koruması, beden bütünlüğünü muhafaza etmeye çalışması iş̧̧iyi koruma borcunun bir gereğidir. Aynı şekilde işverenin işçiyi çalışma ortamında zarara uğratabilecek her türlü durum ve davranışa karşı önlem alması koruma ve gözetme borcu kapsamındadır. $\mathrm{Bu}$ borcun kapsamına sadece işçinin vücut bütünlügünü korumak değil kişiliğini, onurunu, mesleğini ve manevi değerlerini korumak da dahildir.

6331 sayılı İş Sağlığı ve Güvenliği Kanunu yukarıda da ifade edildiği üzere hem kamu hem de özel sektörü bazı istisnalar dışında kapsama dahil etmiştir. Çatı bir kavram olarak işçi ya da memur ayrımı olmaksızın çalışan kavramı kullanılarak kavram bütünlüğü sağlanmıştır. Makalemizde, çalışanların işyerinde faaliyette bulunurken meydana gele- bilecek tehlikelere karşı işveren tarafından bazı yükümlülükler yerine getirilmesi gerektiği, işverenin işyerinde iş sağlığı ve güvenliğine yönelik tedbirleri alınmaması durumunda çalışanların çalışmaktan kaçınma hakkı kavramı incelenecek, koronavirüs salgın hastalığı bakımından da değerlendirmelerde bulunulacaktır.

\section{B. Risk Yönetimi Çalışmaları}

Çalışma ortamında çalışanlar birçok riske maruz kalmaktadır. Bu riskler tehlikeye dönüşmekte ve iş kazaları ve meslek hastalıkları meydana gelebilmektedir. Yukarıda da ifade edildiği üzere işverenler üzerlerine düşen yükümlülükleri yerine getirmediği durumlarda çalışanlara da bazı tedbirler alma hakkı doğmaktadır. Bu haklardan bir tanesi de çalışmaktan kaçınma hakkıdır. Çalışanın çalışma ortamında sağlık ve güvenliği için ciddi ve yakın bir tehlikenin devam etmesi durumunda mevzuatın kendisine tanımış olduğu hakka çalışmaktan kaçınma hakkı denir [1]. Bu durumda çalışmaktan kaçınma hakkında önemli bir kavram olan tehlike kavramını da açılamak yerinde olacaktır. 6331 sayılı İş Sağlığı ve Güvenliği Kanunu 3.maddesinde tehlike kavramı tanımlanmıştır. İlgili hükme göre tehlike "İsyerinde var olan ya da dı̧sarıdan gelebilecek, çalışanı veya işyerini etkileyebilecek zarar veya hasar verme potansiyelidir."

İş sağlığı ve güvenliğine yönelik 6331 sayılı İş Sağlığı ve Güvenliği Kanunu yürürlük tarihinden önce de 4857 sayılı İş Kanunu 83.maddesinde işçilerin sahip olduğu haklar düzenlenmiştir. $\mathrm{Bu}$ haklardan bir tanesi de işçinin çalışmaktan kaçınma hakkıdır. İlgili hükümde "işşi, işyerinde iş sağglğgı ve güvenliği açısından sağglğın bozacak bir teblike ile karşıllaşırsa, tehlike giderilinceye kadar iş görmekten kaçınabilir.” şeklinde ifade edilerek iş̧̧inin sağlık ve güvenliğini tehdit edecek bir tehlike ile karşılaşıldığında işveren tarafından tehlike giderilinceye kadar işçiye çalışmaktan kaçınma hakkı tanınmıştır. Bu mülga kanun hükmünün gerekçesin- 
de de çok açık bir şekilde belirtildiği üzere işçiler iş sağlığı ve güvenliği tedbirlerinin alınmadığı, mesleki risklerle karşılaşma riskinin yüksek olduğu bir çalışma ortamında çalışmaya zorlanamayacaktır. Gerekli tedbirlerin alınmaması durumunda da yine kanunda belirtilen kurula başvurma gibi usuli şartları yerine getirilmesi durumunda gerekli önlemler alınıncaya kadar işçinin çalışmaktan kaçınabileceği hüküm altına alınmıştır [2]. Gerekli tedbirlerin alınmaması durumunda ise işçi iş sözleşmesini derhal feshedebilecektir.

İş Sağlı̆̆ı ve Güvenliği Kanunu'nun müstakil bir Kanun olarak yürürlüğe girmesi ile birlikte İş Kanunu m.83 yürürlükten kaldırılarak bazı değişikliklerle birlikte 6331 sayılı Kanun'un “Çalışmaktan kaçınma hakkı” başlığıyla 13.madde hüküm altına alınmıştır. 6331 sayılı Kanunda, İş Kanunu'nunun mülga 83.maddesinden farklı olarak işyerindeki tehlikenin "hayati" olması yerine "ciddi" olması şartını lehe bir düzenleme olarak getirilmiştir [1,3-5].

Daha önce de ifade edildiği üzere 6331 sayılı İş Sağlığı ve Güvenliği Kanunu, kanunda belirtilen istisnalar haricinde tüm çalışanlara kamu ve özel sektör ayrımı yapılmaksızın uygulanacaktır. Bu düzenleme ile çalışan kavramı getirilerek kapsam genişletilmiş, sadece işçiler değil memurlar ve diğer personel, çırak ve stajyerler de kapsama dahil edilmiştir. Yani Çalışmaktan kaçınma hakkı işçileri tanındığı gibi memurlar ve diğer kamu personeline de tanınmıştır.

\section{II. ÇALIŞMAKTAN KAÇINMANIN ŞARTLARI}

6331 sayılı İş Sağlığı ve Güvenliği Kanunu’ndaki “Çalışmaktan Kaçınma Hakkı” ndan çalışanın faydalanabilmesi için bazı şartların meydana gelmesi gerekir. Şartların gerçekleşmesiyle çalışanın bu haktan faydalanabilmesi için belirli bir usulü takip etmesi gerekir. Aşağıda da çalışmaktan kaçınma hakkından yararlanabilme şartlarına değinilecektir.

\section{A. Çalışanın Çalışma Ortamında Ciddi ve Yakın Tehli- ke İle Karşılaşması}

Çalışanın çalışmaktan kaçınma hakkı söz konusu olabilmesi için öncelikle işyerinde çalışanın sağlık ve güvenliğini tehdit eden ciddi ve yakın bir tehlike olması gerekir [6]. Yakın bir tehlikeden anlaşılması gereken ise tehlikenin kısa bir zaman içinde gerçekleşeceğidir [5,7]. Tehlikenin ciddi olmasından ise çalışanın edimini ifa ederken olağanın üzerinde bir tehlike ile karşılaşması ve olağanüstü tehlikenin çalışanın sağlık ve güvenliğine zarar vereceğinin ihtimal dahilinde olduğu anlaşılmaktadır[8]. Tehlikenin ciddi olup olmadığı hususu her somut olaya göre ayrı ayrı değerlendirilmelidir. Eğer çalışanlar işyerindeki ciddi ve yakın tehlikenin önlenemez olduğu kanaatine varırlarsa aşağıda belirtilecek olan iş sağlığı ve güvenliği kurulu, olmayan yerlerde ise işverene başvuruda bulunmaksızın işyerini ve tehlikeli bölgeyi terk edebilecekler. 6331 sayılı İSGK. Madde13/son daki "Çalışanlar ciddi ve yakın tehlikenin önlenemez olduğu durumlarda birinci fikradaki usule uymak zorunda olmakszın isyerini veya tehlikeli bölgeyi terk ederek belirlenen güvenli yere gider. Çalışanları bu hareketlerinden dolayı hakları kısıtlanamaz" hükmüyle bu husus açıklığa kavuşturulmuştur.

Koronavirüs salgını nedeniyle dünyanın her yerinde olduğu gibi Türkiye'de de çalışma yaşamı önemli derecede sekteye uğramıştır. Salgın hastalık hızla yayılmaya devam ettiği için çalışanlar doğal olarak işyerlerinde çalışmalarına devam etmek konusunda korkuya kapılmaktadır. Çünkü koronavirüs salgını nereden ve kimden bulaşacağı tespit edilemeyen bir salgındır[23] . Kanaatimizce bu salgın çalışanlar için işyerlerinde ciddi ve yakın tehlike kapsamına değerlendirilebilmelidir. Örnekleme üzerinde açıklanacak olursa: bir işyerinde işveren faaliyetine devam ettiği dönemde çalışanlardan birisinin koronavirüs salgın hastalığına yakalandığı ve sağlık kuruluşlarınca da bu durumun 
tespit edildiği öğrenildiğinde, bu virüsün o çalışan ile birlikte aynı işyerinde çalışanlardan kime ne zaman bulaştığının bilinemeyeceği bir durumda kanaatimizce bu husus diğer çalışanlar için ciddi ve yakın bir tehlike olacaktır. Aynı şekilde böyle bir vakıanın varlığında ise çalışanın çalışmaktan kaçınma hakkı unsurlarından ilkinin gerçekleştiği kabul edilmelidir.

\section{B. Çalışanın Ciddi ve Yakın Tehlikenin Tespiti İçin İş} Sağlığı ve Güvenliği Kuruluna, Kurulmadığı İşyerlerinde İse İşverene Başvurması

Çalışanlar işyerinde ciddi ve yakın tehlikenin varlı̆̆ını tespit ettikten sonra bu durumu işyerindeki iş sağlı̆̆ ve güvenliği kuruluna, işyerinde iş sağlığı ve güvenliği kurulu mevcut değilse işverene başvurarak gerekli tedbirlerin alınmasını talep edecektir [9,22]. Eğer kurul ya da işveren çalışanın talebinin geçerli bir talep olduğuna karar verirse çalışanlar gerekli tedbirler alınana kadar çalışmaktan kaçınabilecektir [10]. Bu hususta da 6331 sayılı İSGK. Madde13/1 ve 13/2'de hüküm altına alınmıştır. İlgili hüküm “(1) Ciddi ve yakın tehlike ile karşı karşıya kalan çalışanlar kurula, kurulun bulunmadiğa işyerlerinde ise işverene başvurarak durumun tespit edilmesini ve gerekli tedbirlerin alinmasina karar verilmesini talep edebilir. Kurul acilen toplanarak, işveren ise derhâl kararnı verir ve durumu tutanakla tespit eder. Karar, çallşana ve çallş̧an temsilcisine yazılı olarak bildirilir. (2) Kurul veya işverenin çalışanın talebi yönünde karar vermesi hâlinde çalışan, gerekli tedbirler alinincaya kadar çalışmaktan kaçınabilir. Çalışanlarn çalışmaktan kaçındiğg dönemdeki ücreti ile kanunlardan ve iş sözleşmesinden doğan diğer hakları saklddrr." hususlarını içermektedir. Şunu da ifade etmekte fayda vardır ki çalışanın çalışmaktan kaçınma hakkını kullanabilmesi için tek başına karar vermemesi, iş sağlığı ve güvenliği kurulunun ya da işverenin bu hususla alakalı tedbir ve onayının aranması olağandır.
Çalışan tarafından ciddi ve yakın bir tehlikenin çalışma ortamında ortaya çıktığının işs sağlığı ve güvenliği kuruluna bildirilmesi durumunda iş sağlığı ve güvenliği kurulu acil bir şekilde toplanır, ciddi ve yakın tehlikeli olan durum tutanak altına alınarak tespit edilir. İşs sağlığı ve güvenliği kurulu olmayan yerlerde ise durum işverene bildirildiğinde işveren ivedilikle karar verecektir. Alınan karar hem çalışana hem de varsa çalışan temsilcisine yazılı bir şekilde tebliğ edilir. Eğer aksi bir durum olursa yani çalışan işsağlığı ve güvenliği kurulundan ya da işverenden olumlu bir yanıt almazsa iş sağlığı ve güvenliği ile ilgili olan kamu kurumuna ve yargı makamlarına başvurabilecektir. Yukarıda ilk şartı incelerken de belirtildiği üzere çalışanlar ciddi ve yakın tehlike önlenemez ise yukarıda izah edilen kurul veya işverene başvuru şartına uymaksızın tehlikeli bölgeyi veya işyerini terk ederek güvenli bir alana gidebilme hakkı vardır. Kanaatimizce böyle bir durumda çalışan çalışmaktan kaçınma hakkını kullanabilecektir.

\section{Tehlikenin Devam Ediyor Olması}

Çalışanın ciddi ve yakın tehlikenin varlığı halinde çalışmaktan kaçınma hakkı tehlikeli durum devam ettiği sürece devam etmektedir. Çünkü İSGK. Madde 13/3'te "gerekli tedbirler alınıncaya kadar çalışmaktan kaçınılabilir" hükmü yer almaktadır. Bu hükümden de anlaşıldığı üzere çalışmaktan kaçınma hakkı işveren tarafından ciddi ve yakın tehlikeyi bertaraf edecek önlemler alınıncaya kadar devam edecektir [3,11]. Tehlikeli durum sona ermesine rağmen çalışan çalışmaktan kaçınmaya devam ederse, bu durum işveren açısından haklı nedenle fesih nedeni olabilecektir.

Koronavirüs salgın hastalığının ne kadar süre sonra sona ereceğine yönelik net bir tarih verilmemektedir. Aşı vb. birçok tedavi yöntemi için çalışmalar devam etmesine rağmen gerek Türkiye'de gerekse dünyanın birçok ülkesinde ciddi ve yakın tehlike olan koronavirüs salgını için in- 
sanların gerekli olmadığı müddetçe evlerinden dışarı çıkmamaları yönünde sağlık yetkilileri uyarılarda bulunmaktadır [23]. Bu durumda gösteriyor ki birçok işyerlerinde çalışanlar için salgın ciddi ve yakın tehlike olmaya devam etmektedir. O kadar ki Türkiye'de ciddi ve yakın tehlikeden etkilenecek işverenler ve çalışanlar için kısa çalışma ödeneği, ücretsiz izin, fesih yasağı gibi birçok düzenleme yapılmışıır[25,26,27].

\section{D. İşyerinde İşin Durdurulmamış Olması}

Çalışanın çalışmaktan kaçınma hakkını elde edebilmesi için işyerinde devam eden faaliyetin iş sağlı̆̆ı ve güvenliğinden kaynaklı nedenlerle durdurulmamış olması gerekmektedir. Bu unsur da İSGK. madde13/son'daki hükümden anlaşılmaktadır. İlgili hükme göre eğer işyerinde faaliyet durdurulursa çalışan çalışmaktan kaçınamayacağı gibi özellikle işçinin iş akdini haklı nedenle feshetme hakkı da doğmayacaktır. İşin durdurulması hususu da 6331 sayılı İş Sağlığı ve Güvenliği Kanunu'nda hüküm altına alınmışıtır. İlgili hükme göre "İsyerindeki bina ve eklentilerde, çalışma yöntem ve şekillerinde veya iş ekipmanlarnda çalışanlar için hayati tehlike oluşturan bir husus tespit edildiğginde; bu teblike giderilinceye kadar, hayati tehlikenin niteliği ve bu tehlikeden doğabilecek riskin etkileyebileceğgi alan ile çalışanlar dikkate alınarak, issyerinin bir bölümünde veya tamamında is durdurulur." işin durdurulması ya da işyerinin kapatılması durumunda da çalışan çalışmaktan kaçınma hakkını kullanamayacaktır. Şu kadarı da var ki eğer işyerindeki faaliyet durmuş ya da işyeri kapatılmışsa çalışamayacak olan çalışanın çalışmaktan kaçınma hakkı da olmayacaktır $[12,13,14]$.

6331 sayılı İş Sağlığı ve Güvenliği Kanunu madde 25’e göre "İ̧̧veren, işin durdurulması sebebiyle işsiz kalan çalışanlara ücretlerini ödemekle veya ücretlerinde bir düşüklük olmamak üzere meslek veya durumlarnna göre başka bir iş vermekle yükümlüdür." eğer işveren çalışana çalışma şartlarına uygun farklı bir iş teklif ederse çalışan çalışmaktan kaçınma hakkını kullanamayacaktır [15].

Koronavirüs salgın hastalığı birçok işyerinin kapanmasına birçoğunun ise faaliyetlerinde önemli derece azalmaya gitmesine neden olmuştur. Bu unsur bakımından çalışanın salgın hastalığının ciddi ve yakın aynı zamanda devam eden bir tehlike olduğu gerekçesiyle çalışmaktan kaçınma hakkını kullanabilmesi için işverenin işyerinde faaliyete devam ediyor olması gerekir. Kanaatimizce bu aşamada tam kapasite olmasa da işveren işyerinde faaliyete devam ediyorsa çalışan devam eden ciddi ve yakın tehlikenin varlığını gerekçe göstererek çalışmaktan kaçınma hakkını kullanabilecektir.

\section{III. ÇALIŞMAKTAN KAÇINMANIN HUKUKI SONUÇLARI}

Çalışmaktan kaçınma hakkının şartlarını incelendikten sonra hukuki sonuçları da irdelenerek sonuçlar çıkarılmaya çalışılacaktır. Çalışmaktan kaçınma hakkının şartlarında değinildiği üzere çalışanın bu hakkını kullanabilmesi için işyerinde ciddi ve yakın bir tehlikenin bulunması gerekir. Bunun gibi diğer şartlarından gerçekleşmesi durumunda çalışan çalışmaktan kaçınabilecektir.

A. İşyerinde Tehlike Bulunmadığı Halde, Çalışmaktan Kaçınma Durumu

Özellikle işçi işveren ilişkisi bakımından işverenin ücret ödeme borcuna karşlık iş̧̧inin de iş görme borcu söz konusudur. İşçi iş görme edimini yerine getirmekten kaçınırsa aynı zamanda iş sözleşmesine aykırı davranmış olacaktır. Çalışan da ciddi ve yakın tehlike bulunmamasına rağmen çalışmaktan kaçınırsa sözleşmeye, hukuk kurallarına aykırı olan bu davranışının olumsuz sonuçlarıyla karşı karşıya kalabilecektir. Çalışanın şartları gerçekleşmemiş olan çalışmaktan kaçınma davranışı sonucunda işveren geçerli veya 
haklı nedenle fesih yoluna gidebileceği gibi çalışmaktan kaçınmadan kaynaklı zararların tazmin edilmesini talep edebilecektir $[5,9,15]$.

Şunu da ifade etmekte fayda var ki işyerinde ciddi ve yakın tehlike bulunmamasına rağmen çalışan çalışmaktan kaçınmışsa işveren de ücret ödemekten kaçınabilecektir. Sonuç olarak ücretin hak edilebilmesi için iş̧̧inin iş görme edimini yerine getirmesi gerekir.

Koronavirüs salgın hastalığı hızlı şekilde yayıldığı bu dönemde dahi işverenlerin işyerlerinde iş sağlığı ve güvenliğine yönelik gerekli tedbirleri alma yükümlülügü büyük önem arz etmektedir. İşveren koronavirüs salgın hastalığına karşıllık işyerinde iş sağlığı ve güvenliği önlemlerini ciddi ve yakın bir tehlike olmayacak derece almışsa çalışan da bu önlemleri dikkate alarak çalışmaya devam etmekle yükümlüdür. $\mathrm{Bu}$ aşamada önemli olan husus işyerinde çalışmaya davet eden işverenin, işyerinde ciddi ve yakın tehlike olarak kabul edilebilecek koronavirüs salgın hastalığının bulaşmasını önlemeye yönelik işsağlığı ve güvenliği önlemlerini alıp almadığıdır. Gerekli tedbir alınmış, virüsün bulaşma olasılığı ciddi ve yakın bir tehlike olmaktan çıkacak ortam sağlanmışsa çalışan çalışmaktan kaçınma hakkını kullanamayacak, buna rağmen işe gelmezse geçerli ya da haklı nedenle feshin sonuçlarına katlanmak zorunda kalacaktır [24].

\section{B. Haklı Nedenle Fesih}

Çalışmaktan kaçınma hakkını düzenleyen İSGK 13. Maddesi iş ya da hizmet sözleşmesiyle çalı̧sanlara yönelik bir hüküm de içermektedir. İSGK m.13/4’e göre “ịss sözleşmesiyle çallşanlar, talep etmelerine răgmen gerekli tedbirlerin alınmadiğg durumlarda, tabi oldukları kanun bükümlerine göre iş sözleşmelerini feshedebilir" Bu hükümden de anlaşıldığı üzere iş sözleşmesine istinaden çalışan işçiler yani çalışanlar, iş sağlğ̆ı ve güvenliği kuruluna, olmadığı yerde işve- rene müracaatta bulunup ciddi ve yakın tehlikeyi ortadan kaldıracak tedbirlerin alınmasını istemelerine rağmen gerekli önlemler alınmazsa tabi oldukları kanunlardaki ilgili hükümlere göre iş sözleşmelerini feshedebilecekler[16]. Diğer bir ifadeyle işveren, iş sağlığı ve güvenliği kurulu tarafından verilen çalışanın talebinin yerinde olduğuna dair karara ve işçinin de bu yöndeki talebine rağmen, gerekli tedbirleri almazsa; ilgili işyerinde iş sözleşmesiyle çalışanlar hangi kanun hükümlerine tabi iseler o kanundaki maddelere istinaden iş sözleşmeleri haklı nedenle derhal feshedebilecekler.

İşyerinde ortaya çıkan ciddi ve yakın tehlike işçinin sağlık ve güvenliğini tehdit edebilir. İşçi de tehlikenin ortadan kaldırılması yönünde talepte bulunabilir. Buna rağmen işveren tarafından gerekli tedbirler alınmamışsa işçi lehine haklı nedenle feshin şartları gerçekleşmiş demektir. İlgili hükümde "tabi olduklar kanun hükümlerine göre" ibaresi yer almaktadır. İşçilerin iş sözleşmelerini haklı nedenle feshedebileceği hükmünden dolayı İş Kanunu 24.maddesinin hangi fikra ve bendine istinaden feshedilebileceği sorusu akla gelmektedir. İş Kanunu madde 4/II Ahlak ve İyi niyet kurallarına uymayan haller fikrası $f$ bendinde bu husus düzenlenmiştir. İlgili hükümde “...yahut çalı̧̧ma şartlar uygulanmazsa." ibaresi yer almaktadır. Bu hükümden de anlaşıldığı üzere işveren işyerini iş̧̧ilerin edimlerini ifa edebilecekleri şekilde iş sağlığı ve güvenliğine uygun bir ortamı hazır etmek zorundadır. Eğer çalışma şartlarını uygulamaz gerekli tedbirleri almazsa; işçiler de çalışma şartlarının uygulanmamasından kaynaklı olarak haklı nedenle iş sözleşmelerini feshedebilecekler. İş sözleşmesini haklı nedenle fesheden işçi kıdem tazminatı da talep edebilecektir [17,21]. Şunu da ifade etmekte fayda var ki bu hükümdeki "çalışma şartları uygulanmazsa" ibaresinden işverenin işyerindeki iş sağlığı ve güvenliğine yönelik alması gereken tedbirler de işyerindeki çalışma şartlarından kabul 
edilmektedir. İşveren çalışma şartlarını uygulamazsa işyerindeki iş sağlığı ve güvenliğinin çalışma şartları içinde yer almadığı gibi bir sonucuna ulaşılmaktadır. Bundan dolayı işyerindeki çalışma koşulları uygulanamazsa işçi çalışmaktan kaçınabileceği gibi iş sözleşmesinin haklı nedenle derhal feshedebilecektir.

Yukarıda da ayrıntıya girilemeden ifade edildiği üzere özellikle iş̧̧ilerin iş sözleşmelerini feshedebilmeleri için ciddi ve yakın tehlikenin varlığı halinde ilk olarak iş sağlı̆̆ı ve güvenliği kuruluna, kurulun olmadığı işyerlerinde ise işverene başvurması, kurulun işçinin ileri sürdüğü iddiayı destekler mahiyetteki kararına rağmen gerekli tedbirlerin alınmaması gerekmektedir. Bu sıralama takip edilmeden iş sözleşmesinin feshedilmesi halinde bu durum işçi açısından haklı nedenle fesih nedeni olarak kabul edilmeyecektir [18]. İş sağlığı ve Güvenliği Kanunu'na göre çalışan olarak kabul edilen işçinin haklı nedenle iş sözleşmesini feshedebilmesi işyerinde gerçekleştirdiği faaliyetin ciddi ve yakın tehlike oluşturması ve işin niteliği gereği ortaya çıkan bir tehlike olması gerekmektedir.

Koronavirüs salgın hastalığı o kadar hızlı yayılabilen bir hastalık ki insanlara ne zaman kim tarafından bulaştırıldığının tespiti çok zordur. Bundan dolayı da çalışanlarda ister istemez bir korku ve tedirginlik ortaya çımakta, bulunduğu her ortamda her an virüs bulaşabileceğini düşünmektedirler. İşveren işyerinde koronavirüs salgın hastalığından korunmaya yönelik gerekli bütün tedbirleri aldığı hususunda çalışanını ikna etmesi gerekmektedir. Örnekleme yoluyla açıklayacak olursak: 250 kişinin çalışıı̆ı bir boya fabrikasında çalışanlar arasında birden fazla kişide koronavirüs hastalığı tespit edilmesi durumunda bu olay diğer çalışanlar tarafından ciddi ve yakın tehlike kapsamında değerlendirilebilecektir. Böyle bir durumda çalışanlar işverenden bulaşmayı önleyecek tüm tedbirleri almasını talep edebilirler. Bu talebe rağmen işveren gerekli iş sağlığı ve güvenliği önlemlerini almazsa kanaatimizce çalışanlar iş sözleşmelerini haklı nedenle feshedilme hakkını kazanacaktırlar.

\section{C. Çalışılmayan Süre Ücretinin ve Diğer Haklarının} Ödenmesi

İş Sağlığı ve Güvenliği Kanunu madde 13/4’te iş sözleşmesiyle işverene bağı olarak çalışanların gerek iş sağlığı ve güvenliği kurulu gerekse işverenden talep etmelerine karşılık alınması gerekli olan önlemlerin alınmaması halinde tabi olunan ilgili kanun hükümlerine istinaden iş sözleşmelerini haklı nedenle derhal feshedebilecekleri hüküm altına alınmıştır. 4857 sayılı İş Kanunu madde 24/1'de hüküm altına alındığı üzere derhal fesih hakkı, ya iş sözleşmesindeki edimin ifa edilmesi işin niteliğinden kaynaklı bir nedenden dolayı işçinin sağlık ve güvenliği açısından tehlike arz edecek veya işyerindeki çalışma şartları uygulanmazsa, iş̧̧i tarafından kullanılabilecektir. İşveren tarafından tedbir alınmaması durumunda yine İş Kanunu madde 26 'da hüküm altına alınan 6 günlük hak düşürücü süre işlemeyecektir.

Daha önce de ifade edildiği üzere çalışanın talebi üzere iş sağlığı ve güvenliği kurulu ya da işveren, çalışanın talebi doğrultusunda hareket ederse çalışan gerekli tedbirler alınmadığı müddetçe çalışmaktan kaçınabilecektir. Bununla birlikte çalışanın çalışmaktan kaçındığı dönemde ücreti ödenmek zorundadır [2]. Aynı zamanda çalışan için kanundan ve iş sözleşmesinden doğan diğer hakları da saklı olacaktır. Türk Borçlar Kanunu madde 408'de bu husus hüküm altına alınmıştır. İlgili hükme göre "İ̧̧veren, iş görme ediminin yerine getirilmesini kusuruyla engellerse veya edimi kabulde temerrüde düşerse, işsiye ücretini ödemekle yükümlü olup, iş̧iden bu edimini daha sonra yerine getirmesini isteyemez. Ancak, iş̧̧inin bu engelleme sebebiyle yapmaktan kurtulduğu giderler ile başka bir iş yaparak kazandĭğ 
veya kazanmaktan bilerek kaçındiğı yararlar ücretinden indirilir." Bu hükümden de anlaşıldığı üzere çalışan çalışmaktan kaçınma hakkını usulüne uygun bir şekilde kullanmasına rağmen işveren gerekli tedbirleri almakta kusurlu davranır, hiç yerine getirmez veya eksik olarak yerine getirirse çalışanın ücretini ödemekle yükümlü olacaktır[12,19].

İsyerindeki ciddi ve yakın tehlike önlenebilecek boyutta değilse çalışan İş Sağlığı ve Güvenliği Kanunu madde 13'te hüküm altına alınmış olan prosedüre göre hareket etmek zorunda değildir. Böyle bir durumda işyerini ya da ciddi ve yakın tehlikeli bölgeyi terk edebilecektir. İşveren tarafından önceden belirlenmiş güvenli bölgeye geçebilecektir. Çalışanların böyle bir davranışta bulunmasından kaynaklı haklarının kıııtlanması söz konusu olmayacaktır. Şu kadarı da var ki işveren çalışandan gerek çalışma koşullarında gerekse ücrette bir değişiklik yapmaksızın, iş sağlığı ve güvenliği bakımından tehlike arz etmeyen bir işte edimini ifa etmesini talep edebilecektir. Her ne kadar iş̧̧inin böyle bir talebi kabul etme zorunluluğu olmasa da işçinin bu talebe olumsuz cevap vermesi işçi açısından sadakat borcuna aykırılık teşkil edebilecektir.

İsyerinde ortaya çıkan ciddi ve yakın tehlike birden fazla çalışanı etkileyebilecek durumunda ise gerekli önlemlerin alınması için gerek işs sağlığı ve güvenliği kuruluna gerekse işverene çalışanlar birlikte başvurabilme hakkına sahiptirler. Aynı zamanda diğer şartların da gerçekleşmesi durumunda hep birlikte çalışmaktan kaçınma haklarını kullanmaları işçiler açsından grev teşkil etmeyecektir. Kamudaki çalışanlar da ilgili madde hükmüne göre çalısmaktan kaçınma haklarını kullanmaları durumunda da çalışmaktan kaçındıkları dönemde fiilen çalışmış kabul edilmektedir. İşçiler için hüküm altına alınmış olan çalışmaktan kaçınmada haklı nedenle fesih uygulaması kamu personeli için düzenlenmemiştir. Yani kamu personelinin ciddi ve yakın tehlike olmasına rağmen gerekli tedbirler alınma- ması durumunda kamu görevinden istifa etme hakkı söz konusu değildir.

\section{Alt İşveren İşçileri İle Geçici İş İlişkisiyle Çalışanla- rın İş Görmekten Kaçınma Hakkı}

Teknolojik gelişmeler beraberinde birçok uygulamayı getirmektedir. Bunlardan bir tanesi de işyerinde üçlü iş ilişkileri müessesesidir. Klasik anlamda işyeri işçi ve işverenden oluşmaktaydı. Üçlü iş ilişkilerinde ise işçi, işveren ve diğer işveren işçisi olarak atipik bir iş ilişkisinden oluşmaktadır. Yani bir işyerinde bir asıl işveren ve işçisinin yanında alt işveren işçisi veya geçici süre ile işyerinde edimlerini ifa eden işçiler de bulunmaktadır. Bu noktada önemli olan husus ise işçi ve işverenlerden çok işyerindeki faaliyet ve işyerindeki iş sağlığı ve güvenliği uygulamalarıdır.

Yukarıda da ifade edildiği üzere işverenin işyerinde bizzat kendi işçileri bulunduğu gibi alt işveren işçileri ile geçici iş ilişkisi kapsamında bulunan geçici iş̧̧iler de faaliyette bulunmaktadır. Her ne kadar asıl işveren ile kendi işçileri dışındaki alt işveren ve geçici içiler arasında bir iş sözleşmesi olmasa da bu işçilerin edimlerini ifa ettikleri yer asıl işverenin işyeridir.

Öncelikle her işveren kendi işçileri için iş sağlığ 1 ve güvenliği tedbirlerini almak zorundadır. Bununla birlikte asıl işveren işyerinde alt işveren işçisi olarak çalışan işçiler içinse hem asıl işveren hem de alt işveren gerekli işs sağlı̆̆ ve güvenliği önlemlerini almakla yükümlüdür. Bu bakımdan alt işveren işçileri de İş Sağlığı ve Güvenliği Kanunu madde 13 'te belirtilen usule uygun olarak işyerinde ciddi ve yakın tehlikenin var olması durumunda doğrudan asıl işverene gerekli tedbirlerin alınması için başvurabilecek, çalışmaktan kaçınma hakkını asıl işverene de yöneltebilecekler [18].

Geçici iş ilişkisine istinaden çalışan işçiler bakımından da aynı hükümler geçerlidir. Geçici iş ilişkisinin tarafın 
olan geçici işveren kendi işyerinde çalışan geçici işçiler için de iş sağlı̆̆ı ve güvenliği yükümlülüklerini asıl işverenle birlikte koordineli olarak yerine getirmekle yükümlüdür. Geçici iş ilişkisinin geçici işçileri işyerinde ciddi ve yakın tehlikenin varlığı halinde geçici işverenden gerekli önlemlerin alınmasını talep edebilecekler. Buna rağmen işveren gerekli önlemleri almazsa aynı şekilde İş Sağlığı ve Güvenliği Kanunu madde 13'te belirtilen usule uygun olarak çalışmaktan kaçınma haklarını geçici işverene karşı kullanabilmeleri gerekir[20]. Haklı nedenle fesih hakkını ise asıl işverenine karşı, ciddi ve yakın tehlikenin varlığı, tedbir alınmasını talep etme gibi diğer unsurların da gerçekleşmesiyle birlikte, kullanabilmelidirler.

\section{SONUÇ}

İnsanoğlu tabiatı gereği bulunduğu ortamda bir tehlike ile karşılaştığında zarara uğramamak için biran önce tehlikeli ortamdan uzaklaşmaya çalışır. Yani tehlikeli ortamdan uzaklaşmak, çalışma ortamında ise çalışmaktan kaçınmak hayatın olağan akışına uygun bir davranıştır. Diğer taraftan çalışanın en önemli edimi olan çalışma, iş görme edimini ciddi ve yakın tehlike ortaya çıkması dolayısıyla yerine getirmemesi yani çalışmaktan kaçınması çalışanın vücut bütünlüğünün korumaya yönelik bir hakkıdır.

6331 sayılı İş Sağlı̆̆ı ve Güvenliği Kanunu madde 13’te hüküm altına alınan çalışmaktan kaçınma hakkı ile çalışan çalışma, iş görme ediminden geçici de olsa muaf tutulmaktadır. Olağan bir zamanda bu edimlerin yerine getirilmemesi çalışan açısından sorumlulukları beraberinde getirmektedir. Fakat işyerinde çalışanın iş sağlığı ve güvenliğini tehlikeye düşürecek ciddi ve yakın tehlikenin mevcut olması durumunda çalışmaktan kaçınma hakkı hukuk düzeni tarafından hukuka uygun kabul edilmekte ve korunmaktadir.

6331 sayılı İş Sağlığı ve Güvenliği Kanunu’na göre çalışanın çalışmaktan kaçınma hakkını kullanabilmesi için ciddi ve yakın bir tehlikenin bulunması gerekmektedir. Yeni ortaya çıkan tehlikenin hem ciddi bir tehlike olması hem de yakın bir tehlike olması gerekmektedir. İş Sağlığı ve Güvenliği Kanunu'ndaki düzenleme ile birlikte çalışan çalışmaktan kaçınma hakkını iki şekilde kullanabilecektir. İlkinde çalışanın çalışmaktan kaçınma hakkını kullanabilmesi için ciddi ve yakın tehlikenin varlığını ve tehlikenin giderilmesini iş sağlığı ve güvenliği kuruluna, kurulun olmadığı yerlerde ise işveren bildirmesi, başvuruda bulunması gerekmektedir. Diğer durumda ise ciddi ve yakın tehlike önlenemeyecek, tedbir alınamayacak bir boyutta ise iş sağlığı ve güvenliği kuruluna ya da işveren başvuruda bulunmaksızın çalışmaktan kaçınma hakkını kullanabilecektir.

Kamu işyerleri ile özel hukuk işyerlerinde çalışmaktan kaçınma hakkını kullanmayı gerektirecek olay ve durum ortaya çıkmasına, bağlantılı birçok sorunla karşılaşılmasına rağmen Yargıtay kararları incelendiğinde de anlaşıldı̆̆ı üzere davaya konu olan uyuşmazlık sayısı fazla değildir. Çalışanlar çalışmaktan kaçınma hakkı, unsurları ve kapsamı bakımında gerekli ve yeterli bilgiye sahip değiller. İşverenlerin tarafından da iş sağlığı ve güvenliği bilgi ve eğitim verme yükümlülüğü kapsamında çalışmaktan kaçınma hakkı hakkında gerekli eğitim ve bilgi ayrıntılı bir şekilde verilmemektedir. Bu hale bir de çalışanların ciddi ve yakın tehlike ile karşılaşmalarına rağmen bu durumu iş sağlı̆̆ı ve güvenliği kuruluna ya da işverene bildirmenin iş kaybına yol açabileceği endişesi de eklenince bu durumlar çalışmaktan kaçınma hakkını kullanmalarına engel olabilmektedir. Bununla birlikte özellikle "çalışma koşullarının uygulanmaması" nedeniyle haklı nedenle iş sözleşmesinin işçi tarafından feshedilmesi hakkı işyerinde ciddi ve yakın tehlikenin var olması diğer koşullarında gerçekleşmesiyle birlikte lehe bir düzenleme olarak işçinin işyerinde sağlıklı ve güvenli bir şekilde çalışmasına katkı sağlayacak, işverenin de gerekli 
tedbirleri alması ve denetimleri yerine getirmesini tetikleyecektir.

Koronavirüs salgın hastalığı çalışmaya hayatında işyerlerinde çalışanlar için ciddi ve yakın tehlike kapsamındadır. Çalışanlara hangi ortamda kim tarafından virüs bulaşacağının tespiti çok zor olduğu için çalışan için ciddi ve yakın tehlike kapsamında değerlendirilmelidir. Bu aşamada olağan dönemde az tehlikeli, tehlikeli veya çok tehlikeli işyerlerindeki çalışma koşullarına göre tehlikenin boyutunu ölçme imkanı bulunabilmekteyken koronavirüs salgın hastalığında aynı tespiti yapmak çok zordur. Türkiye'de ve dünyanın birçok ülkesinde bazı işyerleri salgın tehlikesine karşı işe ara verebilmekteyken bazı işyerleri ekonomik nedenler ya da zaruri ihtiyaçların üretildiği işyerleri olmaları gibi nedenlerle faaliyetlerine devam etmek zorunda kalmaktadırlar. Bu işyerlerinde çalışanlar işverenin salgın hastalığı önleyici her türlü iş sağlığı ve güvenliği tedbirlerini alıp almadığını göz önünde bulundurarak çalışmalarına devam etmeleri gerekir. İşveren bütün tedbirleri aldığını, işyerinde bu tedbirler sonrasında koronavirüs salgın hastal1ğının ciddi ve yakın tehlike olmadığını garanti ediyorsa çalışan çalışmaktan kaçınma hakkını kullanamayabilecektir. İşverenin bu yöndeki beyanına rağmen çalışan işyerine gelmezse işveren açısından geçerli ya da haklı nedenle feshin uygulanıp uygulanmayacağı gündeme gelebilir. Çalışan açısından ise işverene koronavirüs salgınının ciddi ve yakın tehlike olduğuna yönelik gerekli bildirimlerde bulunmasına rağmen işveren gerekli tedbirleri almaz, ısrarla çalışanın çalışmaya devam etmesini talep ederse, çalışan da diğer şartların da gerçekleşmesiyle birlikte ciddi ve yakın tehlike bertarafedilenekadar çalışmaktan kaçınma hakkını kullanabilecek, çalışmadığı halde ücretini talep edebileceği gibi haklı nedenle fesih yoluna da gidebilecektir.

\section{KAYNAKÇA}

[1] Aydınlı, İ.,(2005), "İşverenin İşyerinde Çalışan İşçilerin İş Görmekten Kaçınma Hakkı”, Çimento İşveren Dergisi, Cilt:19, sayı:4, 16-17.

[2] Göktaş, S.,(2008), Türk İş Hukukunda İşçinin Çalışmaktan Kaçınma Hakkı, Yekin Yayınları, 2008, Ankara, 228-230.

[3] Balık, D.,(2010), İşçinin İş Sağlı̆ğ ve Güvenliğine ilişkin Tehlike Sebebiyle İş görmekten Kaçınma Hakkı, Legal İş Hukuku ve Sosyal Güvenlik Hukuku Dergisi, s.27, 1007.

[4] Sur, M.,(2005), "İşçinin Çalışmaktan Kaçınma Hakkı”, A.Can Tuncay’a Armağan, İstanbul, 395.

[5] Özdemir, E.(2014), İş Sağlı̆̆ı ve Güvenliği Hukuku, Vedat Kitapçılık, İstanbul, 423.

[6] Kılıç, L.,(2006),İşverenin İş Sağlığı ve Güvenliğinin Sağlama Yükümlülüğü ve Sorumluluğu, Yetkin Yayınları, 1. Baskı, Ankara, 132.

[7] Bostancı, Y.,(2004), İşverenin İş Sağlığı Ve Güvenliğine İlişkin Yükümlülüklerini Yerine Getirmemesi Ve Yaptırımları, Selçuk Üniversitesi Hukuk Fakültesi Dergisi, C. 12, S. 1-2, 81.

[8] Mollamahmutoğlu, H., Astarlı, M., Baysal, U., (2014), İş Hukuku, Turhan Kitapevi, 6. Baskı, Ankara, 1376 .

[9] Sarıbay Öztürk, G.,(2015), İş Sağlığı Ve Güvenliği Yükümlülüklerinin Yerine Getirilmemesinin Hukuki, İdari ve Cezai Sorumlulukları, Beta Yayıncılık, İstanbul, 80,154.

[10] Süzek, S.(2019), İş Hukuku, Beta Yayınevi, 18. Baskı, İstanbul, 913-916.

[11] Oğuz, Ö.,(2011), AB Direktifleri Ve Türk İş Hukukunda İş Sağlığı Ve Güvenliğinde İşverenin Yükümlülükleri ve İşçilerin Hakları, Legal Kitabevi, 1. Baskı, İstanbul, 143-146.

[12] Gümrükçüoğlu, Y.,(2012), İş Sağlığı ve Güvenliğine İlişkin Önlemlerin Alınmaması Sebebiyle İşçinin İş Görmekten Kaçınma Hakkı, Fasikül Hukuk Dergisi, Cilt:4, Sayı:30, s.23-38. 
[13] Güner, R.,(2015), 6331 Sayılı İş Sağlığı ve Güvenliği Kanunu Kapsamında İşin Durdurulması Yaptırımı, Terazi Dergisi, 2015, Cilt:10, Sayı:103, 66.

[14] Süzek, S.,(2005), İşçilerin İş Sağlığı ve Güvenliği Konusunda Hakları ve Yükümlülükleri, Legal İSGHD, 2005, Sayı:6, 618-621.

[15] Soyer, M. P.,(2011), İşçinin İş Görmekten Kaçınma Hakkı, Sarper Süzek'e Armağan, C. I, Beta Yayınevi, İstanbul, 2011, 682.

[16] Sevimli, K. Ahmet: Türk Borçlar Kanunu M. 417 Ve İş Sağlığı Ve Güvenliği Kanunu Işığında Genel Olarak İşçinin Kişiliğinin Korunması, Çalışma Ve Toplum Dergisi, S. 36, 2013/1

[17] Topuz, M.(2007), 4857 Sayılı İş Kanunu Çerçevesinde İşçinin İş Görmekten Kaçınma Hakkı, Maltepe Üniversitesi Hukuk Fakültesi Dergisi, Sayı:2, 2007, 483.

[18] Akın, L.,(2013), İş Sağlığı ve Güvenliği ve Alt İşverenlik, Yetkin Yayınları, Ankara, 244.

[19] Odaman, S.,(2006), İş Sağlığı ve Güvenliği Açısından Tarafların Önemli Hak ve Yükümlülükleri İle Uluslararası Standart, Legal İHSGHD, s. 11, 884-887.

[20] Erdoğan, C., (2017), Geçici İş İlişkisinde İşverenin İş Sağlığı ve Güvenliği Önlemleri Alma Yükümlülüğü, YBHD, Sayı: 2017/2, 127-15.

[21] Baycık, G.,(2013), Çalışanların İş Sağlığı ve Güvenliğine İlişkin Haklarında Yeni Düzenlemeler, Ankara Barosu Dergisi, 118.

[22] Tiftik, M., Adıgüzel, A.,(2016), İş Sağlığı Ve Güvenliği Kanunu'na Göre Genel Hizmet Sözleşmesinde İşverenin İşçiyi Koruma Borcu, YHBD, 340.

[23] İşyerlerinde Koronavirüse (Covıd-19) Karşı Alınması Gereken Önlemler https://www.ailevecalisma.gov.tr

[24] İ. Subaşı Et Al. , "Covid-19 Küresel Salgınının İş ve Sosyal Güvenlik Hukuku Açısından Meydana Getirdiği Sorunlar ve Çözüm Önerileri," In Tüba Covid19 Küresel Salgını, Ankara: Türkiye Bilimler Akademisi, 2020, pp.95-110.

[25] Akın, L. (2020), Covid-19’un İş İlişkilerine Olası Etkileri, Çimento İsveren, C.34, S.3, 15-72.
[26] Centel, T. (2020), Covid-19 Salgını ve Türk Çalışma Yaşamı, Sicil Dergisi, Sayı:43, 11-29.

[27] Yürekli, S.(2020), Çalışma Hayatında Koronavirüs (Covid-19) Salgınının Etkileri. İstanbul Ticaret Üniversitesi Sosyal Bilimler Dergisi, 19 (38) , 34-61. 